\title{
Seroprevalence and associated risk factors of avian influenza virus subtype H9N2 in backyard poultry of Peshawar Pakistan
}

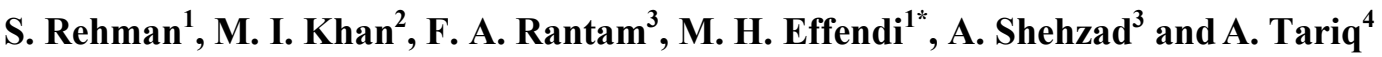 \\ ${ }^{I}$ Division of Veterinary Public Health Faculty of Veterinary Medicine Universitas Airlangga, \\ Surabaya Indonesia \\ ${ }^{2}$ Department of Epidemiology and Public Health University of Veterinary and Animal Sciences, \\ Lahore Pakistan \\ ${ }^{3}$ Laboratory of Virology and Immunology Division of Microbiology, Faculty of Veterinary Medicine \\ Universitas Airlangga, Surabaya Indonesia \\ ${ }^{4}$ Livestock and Dairy Development Department Khyber Pakhtunkhwa Pakistan \\ *Corresponding E-mail:mhelmieffendi@gmail.com
}

Received January 27, 2021; Accepted July 10, 2021

\begin{abstract}
ABSTRAK
Studi saat ini dilakukan untuk memperkirakan prevalensi serologis dan faktor risiko yang terkait dengan penularan subtipe flu burung H9N2 pada unggas yang diumbar di halaman dari berbagai desa di distrik iklim semi-kering Peshawar Pakistan antara Januari hingga Mei 2019. Sejumlah 240 sampel darah dari unggas sehat yang diumbar di halaman dan berumur lebih dari dua bulan, dikumpulkan dari 30 desa berbeda di kabupaten Peshawar. Kuesioner digunakan untuk mengumpulkan data. Sampel serum diuji melalui uji haemagglutination inhibition (HI) yang selanjutnya dikonfirmasi dengan uji micro-neutralizing $(\mathrm{MN})$. Titer tubuh antibodi $\leq 8$ dianggap negatif. Untuk mengklasifikasikan faktor risiko, dilakukan analisis Chi-square dan regresi logistik. Seratus lima puluh sampel dinyatakan positif dari 240 sampel dari 30 desa berbeda di Kecamatan Peshawar. Seroprevalensi keseluruhan adalah $62,5 \%$, titer antibodi rata-rata untuk virus flu burung di semua desa adalah 6,8 dan (95\%) interval kepercayaan masing-masing berkisar dari 35,33 hingga 51,70. Tingginya prevalensi antibodi terhadap virus flu burung dalam serum burung menekankan bahwa flu burung memainkan peran penting dalam kompleks pernapasan ayam yang diumbar di halaman di daerah tersebut, dan mungkin di seluruh Pakistan. Untuk menghindari masuknya H9N2, perlu dilakukan hal-hal antara lain inisiatif biosekuriti, sistem pengawasan dan pemantauan sampai batas tertentu, dan vaksinasi.

Kata kunci: Avian Influenza, Unggas Umbaran, Infeksi pernafasan, Peshawar, Seroprevalence
\end{abstract}

\begin{abstract}
The current study was conducted to estimate the serological prevalence and risk factors associated with the transmission of avian influenza subtype H9N2 among backyard poultry from different villages of semi-arid climate district Peshawar Pakistan between January to May 2019. In total, 240 blood
\end{abstract}


samples of healthy backyard poultry older than two months were collected from 30 different villages of district Peshawar. A predesigned questionnaire was used to collect the data related to risk factors. Serum samples were tested through the haemagglutination inhibition (HI) test further confirmed by the micro-neutralizing test $(\mathrm{MN})$. Antibody body titer $\leq 8$ considered negative for prevalence of H9N2. In order to classify risk factors, Chi-square and Logistic regression analyses were performed. Out of 240, 150 were found to be positive. The overall seroprevalence was $62.5 \%$, mean antibody titer for avian influenza virus in all villages was 6.8 and (95\%) confidence interval ranges from 35.33 to $51.70 \%$ respectively. The high prevalence of antibodies to avian influenza viruses in bird serum emphasizes that avian influenza plays an important role in the respiratory infections of backyard chickens in the area, and possibly throughout Pakistan. In order to avoid the introduction of H9N2, biosecurity initiatives, surveillance, monitoring systems, and to some extent, vaccinations are useful tools.

Keywords: Avian Influenza, Backyard Poultry, Respiratory infection, Peshawar, Seroprevalence

\section{INTRODUCTION}

Avian influenza is a disease of viral etiology, RNA-enveloped virus belongs to the family Orthomyxoviridae. It is a highly infectious, contagious disease of birds and other mammals. Because of this infection, billions of poultry were culled annually, and that is why the poultry industry around the world was considered the biggest cause of destruction. The infection mainly reported in the backyard and commercial poultry while the wild aquatic birds such as ducks and waterfowls serve as the main reservoirs of avian influenza virus (Poulson and Brown, 2020). Avian influenza generally identified as bird flu since the late 1800 s and the virus continues adapting and circulating all over the world to the present day.

Currently, in Asia, avian influenza causes massive economical losses in the poultry industry in different time periods (Burns et al., 2006; Lee et al., 2016). According to virus surface proteins i.e., hemagglutinin (HA) and neuraminidase (NA), it is divided into $18 \mathrm{HA}$ and 11NA subtypes respectively. So far there are 18HA and $11 \mathrm{NA}$ subtypes of the influenza A virus have been reported. These all subtypes were collected from wild aquatic birds (Stallknecht \& Brown, 2007; Liu et al., 2019). Similarly, on the basis of disease severity, avian influenza A virus is divided into high pathogenic (H5, H7) and low pathogenic (H9N2). They can also be written shortly as HPAI and LPAI virus (Chambaro, 2015). The H9N2 virus causes mild respiratory tract infections resulting in low mortality in young chicks and reduction in egg production in laying chickens (Siddique et al., 2012) while the HPAIV H5, H7 causes severe respiratory signs resulting in high mortality decrease production that destroyed the poultry industry throughout the world.

Sometimes the clinical signs of avian influenza may be difficult to differentiate from other endemic diseases of poultry (Swayne, 2007; Wasito et al., 2018). Numerous studies show that the occurrence of new cases increased as compare to the past. Similarly, it is reported that avian influenza outbreaks increased up to 100 folds (Ilaria et al., 2006; Cattoli et al., 2010; WHO, 2020). Backyard poultry is characterized by small flocks with low biosecurity measures and represent around $80 \%$ of poultry stocks in many developing countries (Wilson, 2016). Avian influenza subtype H9N2 is nearly endemic in backyard poultry of south Asia. The infected backyard poultry act as a source of infection to commercial poultry. As of December 2006, more than 240 million poultry including chicken, ducks, turkeys, and geese died or had been culled to prevent the spread of $\mathrm{H} 5 \mathrm{~N} 1$ (Chowdhury et al., 2019). It was a general hypothesis that smallholder backyard poultry is naturally at higher risk of highly pathogenic avian influenza than confined and commercial poul- 
try because of lack of biosecurity practices and the virus is continuously oscillating between the rural and commercial poultry (Gompo et al., 2020; Ali et al., 2018).

The first outbreak of avian influenza virus subtype H7N3 occured in Pakistan in October 1994 in Abbottabad, Mansehra, Rawalpindi, and its surrounding areas that killed more than one million broiler breeders. In the year 1996, the 2nd outbreak was reported in Punjab in broiler breeders and commercial poultry rearing areas. During this outbreak, the mortality rate was very low but huge production losses in terms of egg and meat (Siddique et al., 2012). During 2nd outbreak, the causative agent is different from the first which is LPAI subtype H9N2 confirmed from research laboratories. It was a low pathogenic virus so a local vaccine was prepared that used extensively throughout the year 1996 (Umar et al., 2016).

In the year 2003, an outbreak of AIV was reported in layer rearing areas of Karachi that caused high mortality and decreased production. The birds which were non-vaccinated mostly affected. According to studies AI subtype H7N3 and H9N2 were prevalent in Pakistan poultry. In the year 2005, first time in the poultry rearing areas of Gujranwala, Punjab reported respiratory signs and symptoms in birds, which was on probing declared as first confirmed outbreak of AI subtypes H7 and H9 in "Punjab" Province of Pakistan (Abbas et al., 2010; Cheema et al., 2011). The aim of this study was to detect antibody responses to the H9N2 subtype in the serum of backyard chickens in the district Peshawar Khyber Pakhtunkhwa of Pakistan. The results of such surveys will be definitely useful in the design of management programs for H9N2 infections in backyard chickens in Pakistan.

\section{MATERIALS AND METHODS}

Peshawar has a semi-arid climate. From Northsides Peshawar is connected with Charsadda and Mohmand Agency. Khyber Agency is located on its west side. On the south side, Kohat and Orakzai Agency is located while from the east side it is bounded with Nowshera. Summers

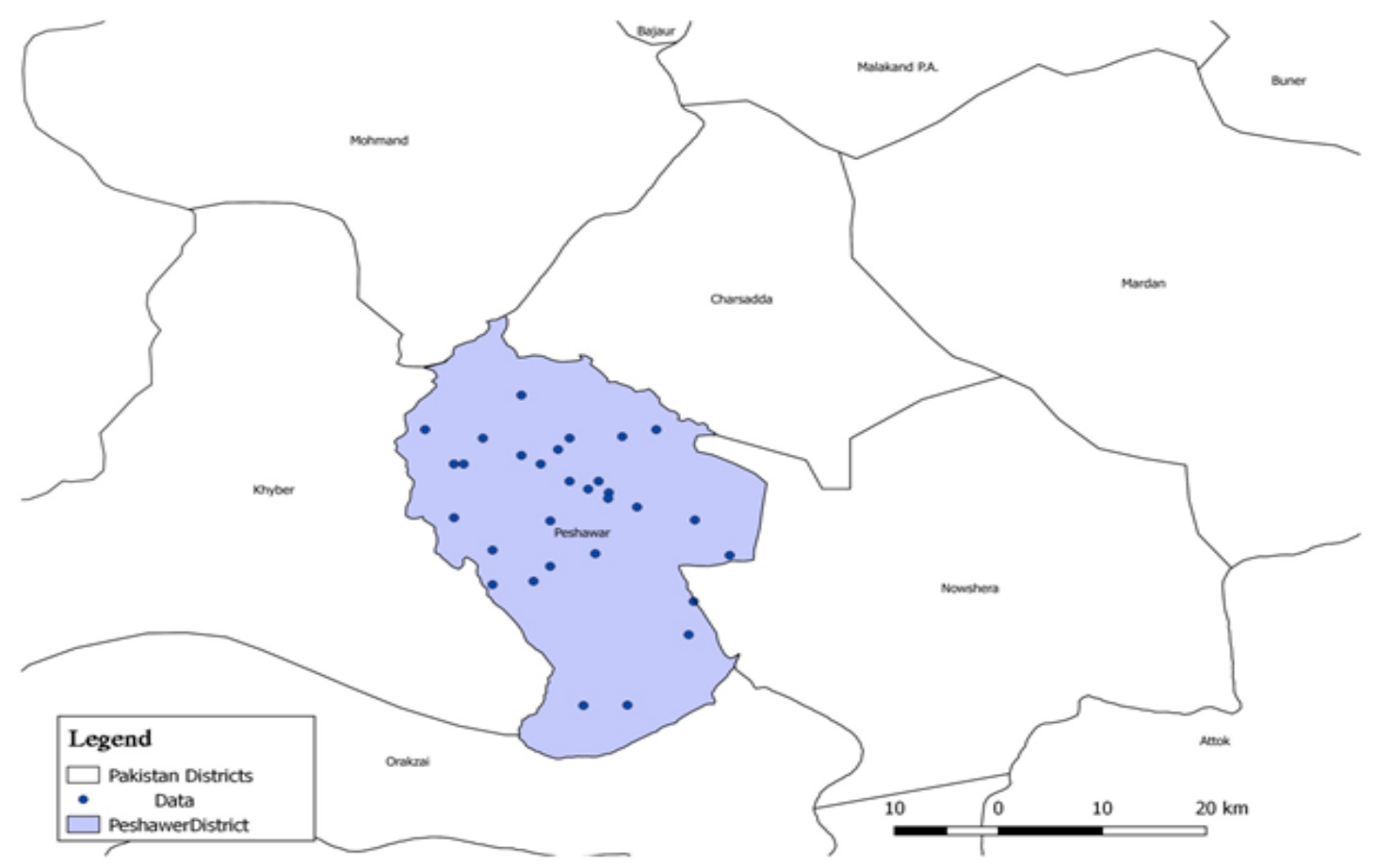

Figure 1. The Study Area, Data and Complete Districts of Khyber Pakhtunkhwa Pakistan 
are very hot and winters are mild. In Peshawar, winter starts in November and then ended in late March. Sometimes extends to the first week of April. Similarly, summer starts from mid of May to September. The mean maximum summer temperature surpasses $40{ }^{\circ} \mathrm{C}\left(104^{\circ} \mathrm{F}\right)$ during the hottest month, and the mean minimum temperature is $25^{\circ} \mathrm{C}\left(77^{\circ} \mathrm{F}\right)$. The mean minimum temperature during the coolest month is $4{ }^{\circ} \mathrm{C}\left(39^{\circ} \mathrm{F}\right)$, while the maximum is $18.3{ }^{\circ} \mathrm{C}$ ( $\mathrm{Pak}$ Met 2010). Latitude and longitude coordinates are 34.025917, 71.560135. Peshawar is a large historic city, the capital of Khyber Pakhtunkhwa Pakistan.

A stratified two-stage cluster sampling method was used to conduct the cross-sectional survey (Kozak et al., 2008). The survey was conducted (January-May 2019) in order to determine the seroprevalence of avian influenza subtype H9N2. Thirty (30) villages were chosen as Primary Sampling Units (PSU) from district Peshawar with probability proportionate to size (PPS) with the process of substitution as previously outlined (Bennett et al., 1991). This technique was implemented as there was no full sampling frame available for the population. The sample size was determined by using the epiR package in R software as performed in the reported study of Tarek et al. (2021).

The target population was the apparently healthy poultry having an age of more than two months. A simple random method was used to collect the blood samples. A total of 240 backyard poultry birds were sampled from 30 clusters. In each cluster; eight (8) elementary units (chicken) were sampled. Blood samples from live and apparently healthy backyard birds were collected from brachial veins as described in FAO Health and Production Manual. Blood was allowed to clot for separation of serum. Collected sera were stored in the freezer at $-20^{\circ} \mathrm{C}$ for further laboratory analysis.

Virus Antigen Preparation was done in 9day old embryonated hen eggs. Eggs were placed inside the incubator for 48 hours at $37^{\circ} \mathrm{C}$. After the completion of 48 hours eggs were again candled in a dark room, to avoid faulty vein punctur- ing the dead embryo was selected and placed inside the refrigerator for 3 hours to constrict the blood vessels. After that eggs were opened at the air sac. For the filtration of allantoic fluid one millilitre $(1 \mathrm{ml})$ syringe was used and fluid was collected in $5 \mathrm{ml}$ tubes. Haemagglutination (HA) assady was used to determine the titer of the virus using $1 \%$ washed chicken red blood cells (RBCs). Haemagglutination inhibition (HI) test using positive control (A/chicken/ Pakistan/10RS3039-288-102/2010) antigen was conducted to diagnose sample for avian influenza H9. The (HI) test was followed as described by World Organisation for Animal Health. The antibodies titer $>8$ was considered positive.

The Chi-Square test and Logistic regression were used to determine the P-value, Odd Ratio, and 95\% Confidence Intervals (CI) were calculated in SPSS version 25. Variables with $(\mathrm{P}<0.25)$ were selected for multivariable analysis adopting the manual forward elimination using $(\mathrm{P}<0.05)$ to select the final model.

\section{RESULTS AND DISCUSSION}

One hundred and fifty out of the 240 collected backyard sera were positive for H9N2 antibodies in the HI test. The mean antibody titer for the avian influenza virus in all villages was 6.8. The mean titer of antibodies of birds were significantly higher in tehsil Charsadda as compared to other tehsils. Overall calculated seroprevalence was $62.5 \%$. In the final model, two factors were significantly associated with the seroprevalence of $\mathrm{H} 9$ in the backyard birds $(\mathrm{P}<0.05)$.

The demographic variables of study participants revealed in Table 1 that 74.2 percent of participants were middle, 15.2 percent were secondary, 5.4 percent were illiterate, and 4.6 percent were primary. The results of qualification indicate that in villages most of the people did not know about the disease and have no information about the vaccine which is a significant factor for the endemic nature of AIV in the study region. Most of the people were unemployed in villages, so they have little backyard poultry 
Table 1. Demographic Variables of Study Participant $(n=240)$

\begin{tabular}{|c|c|c|c|c|c|}
\hline Name of Variable & Category & Frequency \% & Mean & S.E Mean & $\begin{array}{c}\text { St. } \\
\text { Deviation }\end{array}$ \\
\hline \multirow{4}{*}{ Qualification } & Illiterate & 5.8 & \multirow{4}{*}{2.99} & \multirow{4}{*}{0.04} & \multirow{4}{*}{0.66} \\
\hline & Primary & 4.6 & & & \\
\hline & Middle & 74.2 & & & \\
\hline & Secondary & 15.4 & & & \\
\hline \multirow{3}{*}{ Marital status } & Married & 99.2 & \multirow{2}{*}{2.01} & \multirow{2}{*}{0.01} & \multirow{2}{*}{0.091} \\
\hline & Divorced & 0.8 & & & \\
\hline & Unemployed & 78.8 & \multirow{4}{*}{1.46} & \multirow{4}{*}{0.07} & \multirow{4}{*}{1.038} \\
\hline \multirow{3}{*}{ Occupation } & Farm worker & 8.3 & & & \\
\hline & Professional & 3.8 & & & \\
\hline & Business & 9.16 & & & \\
\hline
\end{tabular}

S.E Mean= Standard Error Mean, St.deviation= Standard deviation

farming system that is the main source of income.

The results of Table 2 showed risk factors that significantly associated with H9N2 seropositivity. These were two in number, wild birds contact with backyard poultry flock and bird respiratory signs. They showed a significant association with the seropositivity of H9N2 on the basis of P-value that is less than 0.05 . Out of 240 flocks, 104 were positive with $\mathrm{H} 9$ seropositivity. If we see respiratory signs in birds out of 240 birds, 116 birds showed positive signs with H9 seropositivity. In another study conducted by Wang et al. (2013) in China, wild birds reported contact with backyard poultry flocks. They demonstrated a strong correlation with the seropositivity of infection with avian influenza viruses, which is the key risk factor for disease transmission because wild birds are the natural reservoirs of avian influenza (Wang et al., 2013).

In an earlier study conducted in Pakistan by Zhang et al. (2021) wild birds were investigated as important risk factors correlated with avian influenza virus seropositivity. They indicated that wild birds transmit the infection through direct contact or through contaminated sources of water, such ponds, canals and tanks of water (Fang et al., 2008; Si et al., 2013).

Table 2. Significant Risk Factor Analysis Associated with Seroprevalence of H9

\begin{tabular}{|c|c|c|c|c|c|c|}
\hline \multirow{2}{*}{ Name of Variable } & \multirow{2}{*}{ Exposure } & \multicolumn{2}{|c|}{ Serology results } & \multirow{2}{*}{ OR } & \multirow{2}{*}{$95 \% \mathrm{CI}$} & \multirow{2}{*}{$\begin{array}{c}\mathrm{P} \\
\text { value }\end{array}$} \\
\hline & & Positive & Negative & & & \\
\hline \multirow{2}{*}{$\begin{array}{l}\text { Wild Birds contact with } \\
\text { Flock }\end{array}$} & Yes & 104 & 26 & \multirow{2}{*}{0.2} & \multirow{2}{*}{$.044-.950$} & \multirow{2}{*}{0.00} \\
\hline & No & 46 & 64 & & & \\
\hline \multirow{2}{*}{ Respiratory signs } & Yes & 116 & 113 & \multirow{2}{*}{0.23} & \multirow{2}{*}{$\begin{array}{c}0.048- \\
1.079\end{array}$} & \multirow{2}{*}{0.043} \\
\hline & No & 9 & 2 & & & \\
\hline
\end{tabular}


The numerous risk factors associated with seropositivity of H9N2 but not significant in the current study are shown in Table 3 . Some of these variables were important in earlier studies, such as the presence of dogs and cats in the houses, the watering system of the birds, the rearing system of the birds, and the disposal of dead birds.

The antibody titers of the four tehsils of the district Peshawar are shown in Table 4. The maximum positive cases were found in tehsil Charsadda because of its hilly origin. AIV H9N2 is more prevalent in this tehsil as compared to others. Minimum cases have been reported in tehsil Peshawar because the weather is hot, so in this tehsil, there are minimum chances of AIV infection. The total seroprevalence of avian influenza in district Peshawar is high.

H9N2 has been reported from different countries including Pakistan and this subtype is enzootic throughout Asia (Capua \& Alexander, 2009). H9N2 viruses are not highly pathogenic for poultry, although opportunistic pathogens and immunosuppressive infections can compromise this infection. For the early detection and surveillance of infection serological test are very important. In this regard, ELISA, HI, Gel Immunodiffusion and Neuraminidase Inhibition were the four recommended major tests (Slusher et al., 2014). HI is more specific and more commonly

Table 3. Descriptive Variables of The Study Associated With Seropositivity Of AIV

\begin{tabular}{|c|c|c|c|c|c|c|c|}
\hline \multirow{2}{*}{ Variables } & \multirow{2}{*}{ Exposure } & \multicolumn{2}{|c|}{ Serology results } & \multirow{2}{*}{$\begin{array}{l}\text { Chi- } \\
\text { Square }\end{array}$} & \multirow{2}{*}{$\begin{array}{c}\text { P- } \\
\text { Value }\end{array}$} & \multirow{2}{*}{ OR } & \multirow{2}{*}{$95 \% \mathrm{CI}$} \\
\hline & & Positive & Negative & & & & \\
\hline \multirow{2}{*}{ Presence of Dogs } & Yes & 98 & 55 & \multirow{2}{*}{0.434} & \multirow{2}{*}{0.579} & \multirow{2}{*}{1.19} & \multirow{2}{*}{$0.69-2.06$} \\
\hline & No & 52 & 35 & & & & \\
\hline \multirow{2}{*}{ Presence of Cats } & Yes & 95 & 59 & \multirow{2}{*}{0.121} & \multirow{2}{*}{0.782} & \multirow{2}{*}{0.91} & \multirow{2}{*}{$0.52-1.57$} \\
\hline & No & 55 & 31 & & & & \\
\hline \multirow{2}{*}{$\begin{array}{l}\text { Rearing of Birds at same } \\
\text { place }\end{array}$} & Yes & 88 & 50 & \multirow{2}{*}{0.223} & \multirow{2}{*}{0.686} & \multirow{2}{*}{1.14} & \multirow{2}{*}{$0.67-1.92$} \\
\hline & No & 62 & 40 & & & & \\
\hline \multirow{2}{*}{ Rearing system } & Semi cage & 87 & 56 & \multirow{2}{*}{0.416} & \multirow{2}{*}{0.587} & \multirow{2}{*}{1.19} & \multirow{2}{*}{$0.689-2.04$} \\
\hline & Out door & 63 & 39 & & & & \\
\hline \multirow[b]{2}{*}{ Watering System } & Public water & 85 & 53 & \multirow[b]{2}{*}{0.114} & \multirow[b]{2}{*}{0.788} & \multirow[b]{2}{*}{1.1} & \\
\hline & $\begin{array}{l}\text { Street } \\
\text { channels }\end{array}$ & 65 & 37 & & & & $.645-1.9$ \\
\hline & Market & 27 & 21 & & & & \\
\hline Rirds cource & Hawkers & 6 & 2 & 260 & 0405 & $* * *$ & $* * *$ \\
\hline Birds source & NGOs & 1 & 2 & 2.01 & 0.493 & & \\
\hline & Hatch home & 116 & 65 & & & & \\
\hline & Reduce egg & 74 & 49 & & & & \\
\hline Decrease production & Reduce Wt & 76 & 41 & 0.588 & 0.505 & 1.23 & $0.727-2.07$ \\
\hline Dead hirds & Open & 88 & 43 & 0949 & 0349 & 13 & $076-219$ \\
\hline Dead biras & Buried & 62 & 47 & 0.949 & 0.049 & 1.0 & $0.10-2.19$ \\
\hline Presence of Ponds & Yes & 79 & 53 & 088 & 021 & 0.78 & $0.458-1.31$ \\
\hline Presence or Ponds & No & 71 & 37 & 0.88 & 0.21 & 0.18 & $0.458-1.31$ \\
\hline & Yes & 71 & 52 & 2.456 & 0.117 & 0.66 & $0.338-1.12$ \\
\hline Feed share & No & 79 & 38 & 2.450 & 0.111 & 0.66 & $0.338-1.12$ \\
\hline Hand wash & Yes & 86 & 40 & 3747 & 0053 & 168 & $0.99-285$ \\
\hline & No & 64 & 50 & & & & \\
\hline Breeds & Desi & 133 & 83 & 079 & 0506 & 156 & 0691381 \\
\hline & Mix & 17 & 7 & & & & \\
\hline
\end{tabular}

$\mathrm{OR}=$ Odd ratio, $\mathrm{Cl}=$ Confidence Interval, $* * *=$ No value odd ratio and Confidence Interval 
used in diagnostic laboratories for the detection of AIV infection. Our study results suggest that avian influenza subtype $\mathrm{H} 9$ is highly prevalent in four tehsils of district Peshawar Khyber Pakhtunkhwa (KPK).

Maximum positive cases were reported in tehsil Charsadda and minimum cases were reported in tehsil Peshawar. If the titer $\leq 8$ samples were considered negative and $>8$ samples were considered positive. The mean antibody titer of avian influenza virus subtype H9N2 in backyard poultry sera in four tehsils of district Peshawar were $5.8,8,7.6,6.16$, and the seroprevalence was found $58 \%, 66 \%, 63 \%$, and $61 \%$ respectively (Table 4). The overall antibody titer and seroprevalence of the $\mathrm{H} 9 \mathrm{~N} 2$ avian influenza virus were recorded at 6.89 and $62.5 \%$ respectively. In the current study, the risk factors which are significantly associated with seropositivity of $\mathrm{H} 9$ were wild birds contact with flocks and respiratory signs in the birds on the basis of P-value which is $\leq 0.05$.

In an earlier study conducted in Tunisia, respiratory signs and symptoms were found to be major risk factors related with seropositivity of low pathogenic avian influenza H9N2, with mortality rates ranging from $10 \%$ to $30 \%$ and a decline in egg production (Tombari et al., 2013). In a previous study carried out in Pakistan, undertaken by Naeem et al. (2003) and investigate that respiratory signs and symptoms are also a significant factor associated with seropositivity of H9N2 in backyard and broiler chickens (Naeem et al., 2003; Tahir et al., 2020). Another study conducted in the southern region of Pakistan found that 28 out of 50 samples tested positive for avian influenza subtype H9N2 because the birds showed respiratory signs and symptoms that were significantly associated to AIV infection (Ahmed et al., 2009). According to Norouzian et al. (2014), the H9N2 subtype of avian influenza (AI) virus was isolated from backyard poultry farms in Iran between 2010 and 2011 and was associated with significant mortality and respiratory problems (Norouzian et al., 2014).

The second risk factor in our analysis that demonstrated a significant association with H9N2 seropositivity was wild bird contact with a backyard flock. In a previous study conducted in Bangladesh, backyard chickens reared in a semiscavenge system came into touch with wild ducks and other migratory birds, that showed significant association with AIV subtype H9N2 infection in backyard poultry (Capua \& Alexander, 2004; Caron et al., 2010).

Wild birds like ducks and other migratory birds were avian influenza reservoirs, they are the primary source of infection in backyard chickens (Sohaib et al., 2010). Although most of the studies in other countries concerning H9 have been carried out in commercial birds, some of them have reported high seroprevalence of $\mathrm{H} 9$ among backyard birds; for instance, in a research that was carried out in Oman in 2012, the seroprevalence was $84 \%$ and high exposure to wild birds, continued introduction of new birds to vil-

Table 4. Antibody Titer of AIV in Four Tehsil of District Peshawar

\begin{tabular}{llllllll}
\hline \multirow{2}{*}{\begin{tabular}{c} 
Name of Tehsil \\
\multicolumn{2}{c}{ Positive Samples }
\end{tabular}} & $1: 16$ & $1: 32$ & 0.086 & 0.131 & 0.219 & 0.397 \\
\cline { 2 - 8 } & $35(58 \%)$ & 7 & 10 & 7 & 6 & 4 & 1 \\
\hline Peshawar & $40(66 \%)$ & 7 & 11 & 9 & 5 & 8 & $*$ \\
Charsadda & $38(63 \%)$ & 9 & 13 & 6 & 6 & 4 & $*$ \\
Swabi & $37(61 \%)$ & 5 & 13 & 7 & 6 & 6 & $*$ \\
Mardan &
\end{tabular}

HI dilution= Haemaglutination inhibition dilution, *= No antibody titer 
lages, co-mixing of the birds among neighbour and feeding of uncooked poultry waste is mentioned as the causes of the high seroprevalence (Al Shekaili et al., 2015).

Various AI viruses have been reported in Pakistan poultry populations since 1998 , causing mutations through $\mathrm{H} 5$ and $\mathrm{H} 7$ to produce new H9N2 strains. All reported H9N2 viruses collected during 2009, 2010, 2012, and 2015 in Pakistan were reassortants between the G1 lineage and the H7N3 HPAIV, which was found in Pakistan and carried many mammalian host-specific markers (Siddique et al., 2012). H10N8 donating internal genes, raising public health concern globally.

In the current study out of 240 samples, 150 were positive that indicated the high prevalence of avian influenza subtype H9N2 in four tehsils of district Peshawar Khyber Pakhtunkhwa (KPK). Furthermore, the current study was a cross-sectional survey; these study designs are not suited to estimate disease incidence, the natural history of the disease, or the rate of secondary infection. Cross-sectional studies are also relatively weaker in establishing causality of risk factors than with an analytic design, such as with a cohort study. Well-designed prospective epidemiological studies with follow-up of backyard poultry birds will be better suited to answer such questions.

\section{CONCLUSION}

In summary, the high seroprevalence of H9 has been reported in backyard poultry in the district of Peshawar. We have also found evidence of $\mathrm{H} 9$ virus co-circulation in backyard poultry in the same district, presenting an ongoing threat to the emergence of new AIV genotypes via intra- and inter-subtopic reassortment. Government initiatives to minimize the prevalence of AIVs in these tehsils could decrease the risk of new viruses emerging. To detect any ongoing public health risk, continued active surveillance and genetic characterization of H9N2 are strongly recommended. Studies using onehealth strategy, combined with clinical and viro- logical surveillance in the target population, would be needed to document any cross-species transmission of novel avian influenza viruses.

\section{ACKNOWLEDGEMENTS}

The authors are highly grateful to all the people, who participated in the study and provided data and samples of backyard poultry. Without their help, and positive cooperation, this study would not have been possible. We are also highly obliged to the Livestock and Dairy Development Department KPK for providing the baseline data and support during study.

\section{REFERENCES}

Ahmed, A., T. A. Khan, B. Kanwal, Y. Raza, M. Akram, S. F. Rehmani and S. U. Kazmi. 2009. Molecular identification of agents causing respiratory infections in chickens from southern region of Pakistan from October 2007 to February 2008. Int. J. Agric. Biol, 11(3), 325-328.

Al Shekaili, T. H. Clough, K. Ganapathy and M. J. P. V. M.Baylis. 2015. Sero-surveillance and risk factors for avian influenza and Newcastle disease virus in backyard poultry in Oman. 122(1-2), 145-153.

Ali, M., T. Yaqub, N. Mukhtar, M. Imran, A. Ghafoor, M. F. Shahid and M. Naeem. 2018. Prevalence and phylogenetics of H9N2 in backyard and commercial poultry in Pakistan. Avian Dis. 62(4): 416-424.

Bennett, S., T. Woods, W. M. Liyanage and D. L. Smith. 1991. A simplified general method for cluster-sample surveys of health in developing countries. World health statistics quarterly 1991; 44(3): 98106.

Burns, A., D. Van der Mensbrugghe and H. Timmer. 2006. Evaluating the economic consequences of avian influenza (p. 6). Washington, DC: World Bank. Retrieved from: https://documents.worldbank.org/en/ publication/documents reports/ documentdetail/977141468158986545/ 
evaluating-the-economic-consequences-ofavian-influenza.

Capua, I. and D. J. P. S. Alexander. 2009. Avian influenza infection in birds: a challenge and opportunity for the poultry veterinarian. 88(4), 842-846.

Capua, I. and D. J. P. S. Alexander. 2004. Human health implications of avian influenza viruses and paramyxoviruses. Eur J Clin Microbiol Infect Dis, 23(1), 1-6.

Cattoli, G., A. Fusaro, I. Monne, S. Molia, A. Le Menach, B. Maregeya and I. Capua. 2010. Emergence of a new genetic lineage of Newcastle disease virus in West and Central Africa-implications for diagnosis and control. Vet Microbiol, 142(3-4), 168-176.

Caron, A., M. De Garine-Wichatitsky, N. Gaidet, N. Chiweshe, and G. S. Cumming. 2010. Estimating dynamic risk factors for pathogen transmission using community-level bird census data at the wildlife/domestic interface. Ecol. Soc 15(3): 25. retrieved from: http://www.ecologyandsociety.org/ vol15/iss $3 / \operatorname{art} 25 /$.

Chambaro, H. M. 2015. Characterisation of influenza A H10N1 virus isolated from ducks in Lochinvar National Park Zambia (Doctoral dissertation, University of Pretoria). retrieved from: http:// hdl.handle.net/2263/53320.

Cheema, B. F., M. Siddique, A., Sharif, M. K. Mansoor and Z. Iqbal. 2011. Seroprevalence of avian influenza in broiler flocks in district Gujranwala (Pakistan). Int. J. Agric. Biol. 13(6): 850-856.

Chowdhury S, M.E. Hossain, P.K. Ghosh, S. Ghosh, M.B. Hossain, C. Beard, M. Rahman and M. Z. Rahman. 2019. The Pattern of Highly Pathogenic Avian Influenza H5N1 Outbreaks in South Asia. Trop. Med. Infect Dis. 4(4):138. https:// doi.org/10.3390/tropicalmed4040138.

Fang, L.Q., S. J. de Vlas, S. Liang, C. W. Looman, P. Gong, B. Xu and W.C. Cao. 2008. Environmental factors contributing to the spread of $\mathrm{H} 5 \mathrm{~N} 1$ avian influenza in mainland China. PLoS One. 3(5), e2268. doi:

journal.pone. 0002268

Gompo, T. R., B. R. Shah, S. Karki, P. Koirala, M. Maharjan, D. D. J. P. O. Bhatt. 2020. Risk factors associated with Avian Influenza subtype H9 outbreaks in poultry farms in Kathmandu valley, Nepal. J PloS one, 15(4), e0223550.

Kozak, M., A. Zieliński, S. J. S. Singh and P. Letters. 2008. Stratified two-stage sampling in domains: Sample allocation between domains, strata, and sampling stages. 78(8): 970-974.

Lee, D. H., A. Fusaro, C. S. Song, D. L. Suarez and D. E. Swayne. 2016. Poultry vaccination directed evolution of H9N2 low pathogenicity avian influenza viruses in Korea. Virol. 488: 225-231.

Liu, J. H., C. C. Chang, C. W. Chen, L. T. Wong and Y. W. Chu. 2019. Conservation region finding for influenza $\mathrm{A}$ viruses by machine learning methods of N-linked glycosylation sites and B-cell epitopes. Math. Biosci, 315 (35): 108217. https://doi.org/10.1016/j.mbs.2019.108217

Naeem, K., M. Naurin, S. Rashid and S. Bano. 2003. Seroprevalence of avian influenza virus and its relationship with increased mortality and decreased egg production. Avian Pathol. 32(3): 283-287.

Norouzian, H., M. Bashashati and M. Vasfimarandi. 2014. Phylogenetic analysis of neuraminidase gene of H9N2 avian influenza viruses isolated from chicken in Iran during 2010-2011. Iran. J. Microbiol, 6(2): 91-97.

Poulson, R. L. and J. D. Brown. 2020. Wild Bird Surveillance for Avian Influenza Virus. In Animal Influenza Virus (pp. 93-112): Humana, New York, NY. https:// doi.org/10.1007/978-1-0716-0346-8_8.

Si, Y., W. F. de Boer and P. Gong. 2013. Different environmental drivers of highly pathogenic avian influenza H5N1 outbreaks in poultry and wild birds. PLoS One, 8(1), e53362. https://doi.org/10.1371/ journal.pone. 0053362 
Siddique, N., K. Naeem, M. A. Abbas, Z. Ahmed and S. A. Malik. 2012. Sequence and phylogenetic analysis of highly pathogenic avian influenza $\mathrm{H} 5 \mathrm{~N} 1$ viruses isolated during 2006-2008 outbreaks in Pakistan reveals genetic diversity. Virol J. 9(1): 300. https://doi.org/10.1186/1743-422X-9 -300 .

Slusher, M. J., B. R. Wilcox, M. P. Lutrell, R. L. Poulson, J. D. Brown, M. J. Yabsley and D. E. J. J. O. W. D. Stallknecht. 2014. Are passerine birds' reservoirs for influenza A viruses? 50(4): 792-809.

Sohaib, M., M. Siddique, K. Muhammad, M. Rabbani, I. Altaf and A. Hanif. 2010. Prevalence of avian influenza virus (H5) in poultry layer flocks in and around Faisalabad, Punjab, Pakistan. Pak. J. Zool. 42 (3): 325-329.

Stallknecht, D. E. and J. D. Brown. 2007. Wild birds and the epidemiology of avian influenza. J. Wildl. Dis., 43(3 Suppl.),: S15S20.

Swayne, D. E. 2007. Understanding the complex pathobiology of high pathogenicity avian influenza viruses in birds. Avian Dis. 51 (s1): 242-249.

Tarek, M., M. M. Naguib, A.S. Arafa, L. A. Tantawy, K. M. Selim, S. Talaat and H. A. J. A. Sultan,. 2021. Epidemiology, Genetic Characterization, and Pathogenesis of Avian Influenza H5N8 Viruses Circulating in Northern and Southern Parts of Egypt, 2017-2019. J Animals, 11(8): 2208.

Umar, S., S. Sarfraz, A. Mushtaq and M. Attique. 2016. Emerging threat of H9N2 viruses in poultry of Pakistan and vaccination strategy. Worlds Poult. Sci .J.: 72(2), 343-352.

Wang, Y., Z. Jiang, Z. Jin, H. Tan and B. Xu. 2013. Risk factors for infectious diseases in backyard poultry farms in the Poyang
Lake area, China. PLoS One, 8(6), e67366. https://doi.org/10.1371/ journal.pone.0067366.

Wasito R, H. Wuryastuti and B. Sutrisno. 2018. Detection of mixed infection of Avian Influenza and Newcastle Disease Viruses inchickens in Indonesia by immunopathologic immunohistochemistry doublé staining. Pak. Vet. J. 38(4): 442-445.

World Health Organization. 2020. Increase in 'bird flu' outbreaks - WHO/Europe advice for handling dead or sick birds: https:// www.euro.who.int/en/home

Tahir, M. F., M. A. Abbas, T. Ghafoor, S. Dil, M. A. Shahid, M. M. H. Bullo and P. Health. 2020. Seroprevalence and risk factors of avian influenza H9N2 virus among poultry professionals in Rawalpindi, Pakistan. J. Infect. Publ. Health 13(3): 414417.

Tombari, W., M. Paul, J. Bettaieb, I. Larbi, J. Nsiri, I. Elbehi and A. Ghram, 2013. Risk factors and characteristics of low pathogenic avian influenza virus isolated from commercial poultry in Tunisia. PLoS One, 8(1), e53524.: https:// doi.org/10.1371/journal.pone.0053524.

Wilson, K. R. 2016. How the Improved Chicken Crossed the Road: Assessing models and strategies to implement a chicken breeding and distribution program for smallholder family poultry producers: University of California, Davis. ProQuest Dissertations Publishing, 10193252.

Zang, X., Y. Li, S. Jin, T. Wang, W. Sun, Y. Zhang, and X. J. T. Hu. 2021. H9N2 influenza virus spillover into wild birds from poultry in China bind to human $\square$ type receptors and transmit in mammals via respiratory droplets. J Transboundary Emerging Diseases. https://doi.org/10.1111/ $\underline{\text { tbed. } 14033}$ 